\title{
UJI EFEKTIVITAS DAN UJI IRITASI GEL PEWARNA RAMBUT DARI EKSTRAK BIJI BUAH PEPAYA
}

\author{
(Carica papaya $\mathrm{L})$
}

\author{
Sutriningsih $^{1}$, Zuraida Sagala $^{2}$, Meliana $^{3}$ \\ 1,2,3 Fakultas Farmasi,Universitas 17 Agustus 1945 Jakarta \\ vinnelaras@yahoo.co.id \\ Program Studi Ilmu Farmasi, Universitas 17 Agustus 1945 Jakarta
}

\begin{abstract}
ABSTRAK
Penggunaan bahan sintetis sebagai bahan aktif pada pewarna rambut dapat menimbulkan efek samping pada kulit kepala atau pada rambut. Oleh karena itu, dikembangkan pewarna rambut dengan bahan aktif yang diambil dari bahan alam yang merupakan tanaman asli dari Indonesia. Pepaya (Carica papaya L) adalah tanaman tradisional Indonesia yang diambil bijinya sebagai bahan aktif pada sediaan ini dan telah terbukti secara empiris sebagai pewarna rambut. Tujuan penelitian ini adalah mengembangkan formula dan menguji efektivitas dari sediaan gel dengan bahan aktif yaitu biji buah pepaya (Carica papaya L). Tahap-tahap penelitian terdiri dari penyiapan ekstrak dengan menggunakan pelarut etanol 70\%, biji pepaya dari buah pepaya lokal, pembuatan formula dengan 3 macam konsentrasi yaitu 2\%,3\% dan 4\%, pengujian efektivitas pewarnaan dan uji iritasi pada hewan uji dengan kontrol positif atau bahan pembanding yaitu pewarna rambut Henna yang beredar di pasaran. Hasil penelitian ini menunjukkan bahwa warna alami yang dihasilkan dipengaruhi oleh konsentrasi ekstrak biji pepaya dari berbagai macam konsentrasi. Semakin besar konsentrasi ekstrak akan menyebabkan warna yang dihasilkan menjadi semakin pekat pengamatan efektivitas pewarnaan dilakukan selama 1 bulan dengan warna yang dihasilkan yaitu coklat dan masih tetap stabil selama 1 bulan tersebut. Ketiga formula tidak mengiritasi dan stabil, baik pada suhu kamar, suhu dingin maupun suhu panas. Dengan demikian, ekstrak biji buah pepaya dapat digunakan sebagai pewarna rambut.
\end{abstract}

Kata kunci: biji buah pepaya, pewarna rambut, sediaan gel

\section{PENDAHULUAN}

Rambut merupakan mahkota dan pelindung kepala yang harus dijaga dan dirawat. Warna rambut ditentukan oleh pigmen melanin yang ada pada korteks rambut yaitu eumelanin dan pyomelanin. Perubahan warna rambut dapat terjadi dengan perkembangan usia, rambut mulai kehilangan pigmen yang dapat disebabkan karena menurunnya fungsi melanosit, aktivitas tirosin dan faktorfaktor lainnya.

Pewarna rambut adalah sediaan kosmetika yang digunakan dalam tata rias rambut untuk mewarnai rambut atau mengembalikan warna rambut ke warna asalnya. Berdasarkan jenisnya ada dua pewarna rambut yaitu pewarna rambut sintetis dan alami. Penggunaan sebagian besar pewarna rambut dari bahan sintetis atau bahan aktif yang berasal dari bahan kimia dapat menimbulkan efek samping pada kulit kepala atau rambut. Sebagai alternatif mulai dikembangkan pewarna rambut alami yang bahan aktifnya adalah bahan alam. Salah satu tanaman yang mempunyai khasiat sebagai pewarna rambut adalah biji buah pepaya (Carica papaya L). Dari beberapa penelitian yang telah dilakukan ekstrak biji buah pepaya pernah diteliti sebagai antibakteri ( Nito 2009), antiseptik ( Warisno,2003) Dari kandungan buah pepaya ditemukan adanya alkaloid karpain, karisin dan glikosida kakarindan karpain (Aravind,2013) yang ternyata berkhasiat sebagai pewarna rambut.

Gel adalah salah satu bentuk sediaan farmasi yang bersifat dispersi semisolid yang terdiri dari partikel anorganik yang kecil atau molekul organik yang besar. Gel harus memiliki sifat tidak lengket, bening dan transparan, sifat alir tiksotropik dan pseudoplastik, jumlah bahan penyusun formula yang relatif sedikit dan viskositas yang cenderung konstan menjadikan gel sebagai salah satu pilihan di masyarakat yang paling digemari dalam pembuatan sediaan pewarna rambut. ( Ansel,2008). 
Tujuan penelitian ini adalah untuk mengembangkan formulasi ekstrak biji buah pepaya menjadi bentuk gel pewarna rambut yang menarik, menguji efektivitas gel sebagai sediaan pewarna rambut dan uji iritasi gel dengan bahan aktif dari biji buah pepaya (Carica papaya L).

\section{METODE PENELITIAN}

\section{Bahan}

Bahan-bahan yang digunakan dalam penelitian ini adalah biji buah pepaya, etanol 70\%, carbopol $940 \mathrm{P}$, trietanolamin, gliserin, nipagin, nipasol, aroma green tea, aquadest dan bulu bebek putih.

\section{Ekstraksi biji pepaya}

Ekstraksi biji pepaya dilakukan dengan metode maserasi menggunakan cairan penyari berupa etanol 70\% selama 3x24 jam atau 3 hari pada temperatur kamar dan dilakukan pengulangan tiga kali. Maserat yang diperoleh dipekatkan dengan alat penguap rotary evaporator pada suhu $50^{\circ} \mathrm{C}$ hingga diperoleh ekstrak kental dan kemudian diuapkan lagi di atas penangas air pada suhu $60^{\circ} \mathrm{C}$ hingga diperoleh ekstrak yang lebih kental, namun masih dapat dituang dengan mudah.

Tabel 1. Rancangan Formula ( Hope Ed 6 dan Jurnal Penelitian Farmasi Indonesia)

\begin{tabular}{ccccc}
\hline \multirow{2}{*}{ Bahan } & \multicolumn{3}{c}{ Formula $(\% \mathrm{~b} / \mathrm{b})$} & Fungsi \\
\cline { 2 - 4 } & $\mathrm{F} 1$ & $\mathrm{~F} 2$ & $\mathrm{~F} 3$ & Bahan aktif \\
\hline $\begin{array}{c}\text { Ekstrak biji buah } \\
\text { pepaya }\end{array}$ & 2 & 3 & 4 & Basis gel \\
\hline Carbopol 940 P & 1 & 1 & 1 & Emolien \\
\hline Gliserin & 5 & 5 & 5 & Menjernihkan gel dan membuat \\
Trietanolamin & 1 & 1 & 1 & Pengawet \\
\hline Nipagin & 0.18 & 0.18 & 0.18 & Pengawet \\
\hline Nipasol & 0.02 & 0.02 & 0.02 & Pewangi \\
\hline Aroma green tea & Qs & Qs & Qs & Pelarut \\
\hline Aquadest ad & 100 & 100 & 100 & \\
\hline
\end{tabular}


skema pembuatan sediaan gel pewarna rambut:

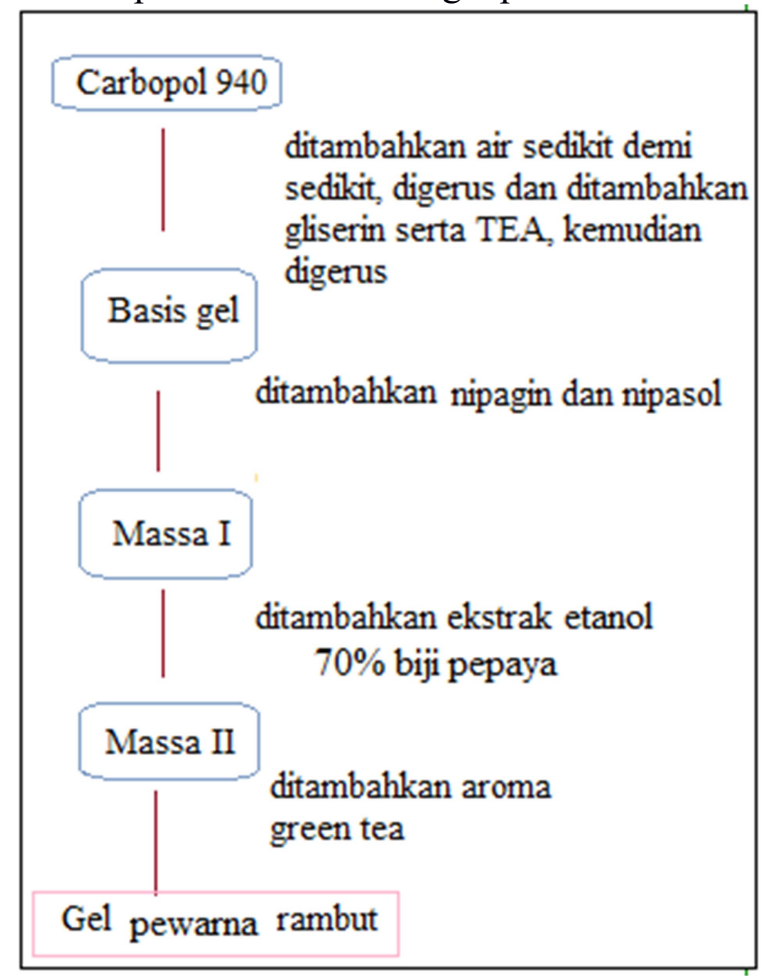

\section{Pengujian efektivitas pewarnaan}

Sediaan uji yaitu gel dioleskan pada bulu bebek secara merata, dibiarkan selama 1 jam, kemudian bulu bebek dicuci dan diamati ada tidaknya perubahan warna yang terjadi pada bulu bebek tersebut. Untuk mengetahui pengaruh pemakaian sediaan gel pewarna rambut secara berulang, dilakukan sebanyak tiga kali (triplo) dan masing-masing didiamkan selama 30 menit.Pengamatan efektivitas pewarnaan ini dilakukan selama 1 ( satu ) bulan dan warna yang di hasilkan masih stabil selama waktu pengamatan tersebut.

\section{Pengujian iritasi}

Pengujian iritasi dari sediaan gel pewarna rambut dengan konsentrasi zat warna terbesar dilakukan dengan menggunakan teknik uji tempel terbuka yaitu sejumlah kecil sediaan uji dioleskan pada kulit telinga kanan kelinci dan sediaan blangko (kontrol negatif) dioleskan pada kulit telinga kiri kelinci. Olesan dibiarkan terbuka selama 1 jam dan diamati reaksi yang terjadi (kemerahan dan rasa gatal). Pengujian dilakukan selama tiga hari berturut-turut.

\section{HASIL DAN PEMBAHASAN}

Obyek percobaan ini adalah ekstrak biji buah pepaya ( Carica papaya L ) yang dibuat menjadi 3 formula gel dan dilakukan sebanyak 3 kali pengulangan pada saat pengujian efektivitas pewarnaan yang dioleskan pada bulu bebek secara merata. Kontrol positif atau pembanding yaitu serbuk Henna pewarna rambut yang sudah beredar di pasaran dan kontrol negatifnya adalah bahan - bahan penyusun formula gel tanpa bahan aktifnya yaitu ekstrak biji buah pepaya ( Carica papaya L ). 
Basis gel yang telah dibuat sebanyak 3 formula dengan basis Carbopol dan eksipien bahan lainnya seperti trietanolamin, gliserin, nipagin, nipasol, aroma green tea dan aquadest serta bahan aktif berupa ekstrak etanol biji pepaya dengan variasi konsentrasi yaitu 2, 3 dan 4\%. Sifat basa dari trietanolamin berperan menetralkan carbopol yang bersifat asam dan sebagai penjernih dari basis carbopol. Gliserin berperan sebagai emolien atau humektan yang mempunyai kemampuan untuk mengikat air (hidrasi). Nipagin dikombinasikan dengan nipasol untuk mendapatkan aktivitas antimikroba yang maksimal. Aroma green tea berperan untuk menutupi bau dari ekstrak biji pepaya dan mempunyai efek menenangkan pada kulit.

\section{Pengujian efektivitas pewarnaan}

Hasil pengujian efektivitas sediaan gel pewarna rambut dapat dilihat pada tabel 2 dan kontrol positif dan negatif dapat dilihat pada tabel 3

Tabel 2. Hasil Pengujian Efektivitas Pewarnaan Sediaan Gel

\begin{tabular}{ccccccc}
\hline \multirow{2}{*}{ Waktu } & \multicolumn{6}{c}{ Warna yang ditimbulkan } \\
\cline { 2 - 7 } & \multicolumn{7}{c}{ Sebelum pencucian } & \multicolumn{3}{c}{ Sesudah pencucian } \\
\cline { 2 - 7 } & F1 & F2 & F3 & F1 & F2 & F3 \\
\hline Awal & Putih & Putih & Putih & Putih & Puth & Putih \\
\hline 1 jam & ++ & +++ & ++++ & + & ++ & +++ \\
\hline 30 menit pertama & + & ++ & +++ & Pudar & + & ++ \\
\hline 30 menit kedua & ++ & +++ & ++++ & + & ++ & +++ \\
\hline 30 menit ketiga & +++ & ++++ & +++++ & ++ & +++ & ++++ \\
\hline
\end{tabular}

Tabel 3. Hasil Pengujian Efektivitas Pewarnaan Kontrol Positif dan Kontrol Negatif

Warna yang ditimbulkan

\begin{tabular}{|c|c|c|c|c|c|c|c|c|}
\hline & & & & & \multirow{2}{*}{\multicolumn{4}{|c|}{ Sesudah pencucian }} \\
\hline \multirow{3}{*}{ Waktu } & \multicolumn{4}{|c|}{ Sebelum pencucian } & & & & \\
\hline & \multicolumn{3}{|c|}{ Kontrol positif } & \multirow{2}{*}{$\begin{array}{c}\text { Kontrol } \\
\text { negatif }\end{array}$} & \multicolumn{3}{|c|}{ Kontrol positif } & \multirow{2}{*}{$\begin{array}{l}\text { Kontrol } \\
\text { negatif }\end{array}$} \\
\hline & $2 \%$ & $3 \%$ & $4 \%$ & & $2 \%$ & $3 \%$ & $4 \%$ & \\
\hline Awal & Putih & Putih & Putih & Putih & Putih & Putih & Putih & Putih \\
\hline 1 jam & ++ & +++ & ++++ & Putih & + & ++ & +++ & Putih \\
\hline \multicolumn{9}{|c|}{ Penggunaan berulang } \\
\hline 30 menit pertama & + & ++ & +++ & Putih & Pudar & + & ++ & Putih \\
\hline 30 menit kedua & +++ & ++++ & +++++ & Putih & ++ & +++ & +++ & Putih \\
\hline 30 menit ketiga & ++++ & +++++ & ++++++ & Putih & +++ & ++++ & ++++ & Putih \\
\hline
\end{tabular}

Keterangan : warna yang dihasilkan adalah coklat. Semakin bertambah nilai $(+)$, warna yang dihasilkan semakin pekat. 
Pengujian efektivitas bertujuan untuk mengetahui konsentrasi yang terbaik dari sediaan gel yang mampu menghasilkan warna yang konstan dan tidak hilang selama pencucian. Hasil pengamatan menunjukkan bahwa adanya perbedaan warna yang dihasilkan dari ketiga formula, dimana pada F3 didapatkan warna yang paling pekat. Semakin besar konsentrasi zat aktif, maka warna yang dihasilkan semakin pekat. Warna yang dihasilkan sebelum dan sesudah pencucian juga menunjukkan adanya perubahan. Setelah pencucian, warna yang didapatkan tampak lebih pudar. Dari penggunaan berulang, didapatkan bahwa semakin lama didiamkan, maka warna yang dihasilkan semakin pekat. Jika dibandingkan dengan kontrol positif, penggunaan selama 1 jam menunjukkan hasil yang sama. Namun pada penggunaan berulang, didapatkan pada pengulangan kedua kontrol positif menghasilkan warna yang lebih pekat.

\section{Pengujian iritasi}

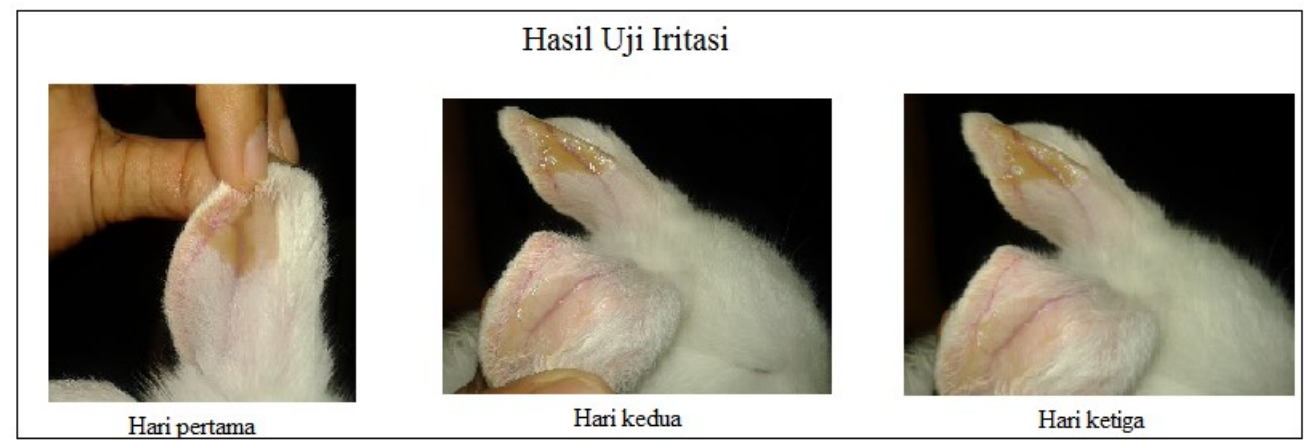

Keterangan gambar hasil pengujian iritasi :

\begin{tabular}{|l|l|}
\hline Waktu & Reaksi yang terjadi \\
\hline Hari Pertama & $\begin{array}{l}\text { Tidak menimbulkan warna } \\
\text { merah dan gatai }\end{array}$ \\
\hline Hari Kedua & $\begin{array}{l}\text { Tidak menimbulkan warna } \\
\text { merah dan gatai }\end{array}$ \\
\hline Hari ketiga & $\begin{array}{l}\text { Tidak menimbulkan warna } \\
\text { merah dan gatai }\end{array}$ \\
\hline
\end{tabular}

Pengujian iritasi bertujuan untuk mengetahui apakah sediaan gel aman digunakan dengan parameter reaksi iritasi apabila diaplikasikan pada kulit. Hasil pengamatan menunjukkan bahwa sediaan gel aman digunakan yaitu tidak menunjukkan reaksi iritasi, baik pada hari pertama, kedua maupun ketiga.

Pengujian stabilitas dilakukan pada 3 temperatur yaitu temperatur kamar, suhu panas $40^{\circ} \mathrm{C}$ dan suhu dingin $4^{0} \mathrm{C}$. Hasil pengamatan menunjukkan bahwa ketiga formula memenuhi kriteria gel yang baik, pada uji organoleptis, homogenitas, viskositas, $\mathrm{pH}$ dan daya sebar. Dengan demikian, dapat dikatakan bahwa ketiga formula stabil. Pada pengujian statistik dengan ANOVA dua arah didapatkan bahwa ada pengaruh suhu, formula dan lama penyimpanan (waktu) terhadap ketiga formula. 


\section{KESIMPULAN DAN SARAN}

\section{Kesimpulan}

1. Pembuatan formulasi gel dengan bahan aktif ekstrak biji pepaya (Carica papaya L) dengan menggunakan basis carbopol yang fungsinya sebagai gelling agent dapat membentuk sediaan gel yang stabil.

2. Perubahan warna pada efektivitas dipengaruhi oleh konsentrasi jumlah zat aktif dan pengaruh dari penggunaan berulang.

3. Formula sediaan gel yang paling baik adalah formula 3 dengan konsentrasi bahan aktif sebesar $4 \%$.

4. Pengamatan pada pengujian efektivitas pewarnaan dilakukan selama 1 bulan dan selama waktu tersebut efektivitas warna yang dihasilkan dari ekstrak biji buah pepaya tetap stabil dan tidak berubah yaitu berwarna coklat.

5. Penggunaan Henna pewarna rambut pada penelitian ini berfungsi sebagai kontrol positif atau pembanding dengan tujuan membandingkan efektivitas dari pewarna rambut biji buah pepaya ( Carica papaya L ) atau paling tidak mempunyai efektivitas dan kestabilan yang sama.

6. Ekstrak biji buah pepaya ( Carica papaya L ) dapat digunakan sebagai pewarna rambut alami dan sebagai alternatif dalam pemilihan bahan aktif selain bahan kimia.

\section{Saran}

Perlu dikembangkan penggunaaan bahan alam lain yang mempunyai khasiat sama sebagai pewarna rambut dan pengembangan bentuk sediaannya.

\section{DAFTAR PUSTAKA}

Anggraini, Deni. (2005) : Formulasi Krim Serbuk Getah Buah Pepaya (Carica papaya L) Sebagai Anti Jerawat. Skripsi. Sekolah Tinggi Ilmu Farmasi Riau, Fakultas Farmasi Universitas Andalas.

Anggraini, Deni. (2013) : Formulasi Gel Antijerawat dari Ekstrak Etil Asetat Gambir. Jurnal Penelitian Farmasi Indonesia Page 62-66.

Anief, M. (2007). Farmasetika. Cetakan Keempat. Gadjah Mada University Press : Jogjakarta

Ansel. (2008) : Pengantar Bentuk Sediaan Farmasi Edisi Keempat. Penerbit Universitas Indonesia (UI-Press) : Jakarta

Aravind G. (2013) : Traditional and Medicines Uses of Carica papaya. Journal of Medicinal Plants Studies Volume I page 7-15.

Ariani, Dewi. (2011) : Stabilitas Fisika dan Kimia Sediaan Gel dan Tonik Penyubur Rambut dari Ekstrak Etanol Biji Anggur (Vitis vinifera L) var. Merah. Kongres Ilmiah XIX dan Rapat Kerja Nasional Ikatan Apoteker Indonesia 2011. Fakultas Farmasi Universitas Surabaya.

Atwood, D. dan A.T. Florence. (2008). Physical Pharmacy. Pharmaceutical Press :Grayslake, USA

Brahmono, Rifki. (2012) : Isolasi dan Karakterisasi Senyawa Alkaloid Dari Biji Tumbuhan Sirsak (Annona muricata Linn). Skripsi. Jurusan Pendidikan Kimia Fakultas MIPA, Universitas Negeri Gorontalo.

Buchmann. (2001). Main Cosmetic Vehicles, in Barel, A. O., Paye, M., and Maibach, H.,I. Handbook of Cosmetic Science and Technology. Marcel Dekker Inc : New York 
Departemen Kesehatan Republik Indonesia. (1995). Farmakope Indonesia $\quad$ Edisi $\quad I V$. Direktorat Jendral Pengawasan Obat dan Makanan : Jakarta

Departemen Kesehatan Republik Indonesia. (2000). Parameter Standar Umum Ekstrak Tumbuhan Obat. Direktorat Pengawasan Obat Tradisional : Jakarta

Effionora, Anwar. (2012). Eksipien dalam Sediaan Farmasi Karakterisasi dan Aplikasi. PT Dian Rakyat : Jakarta.

EK. Marfo. (1989). Chemical Composition of Papaya (Carica papaya) seeds. Elsevier. http:/www.sciencedirect.com/science/article/pii/0308814686900841. Diakses 20 Maret 2016.

Everette. (1974). Carpaine : An Alkaloid of Carica papaya-its Chemistry and Pharmacology. Journal of Economic Botany Page 363-365.

Galih Yunia. (2015). Efektivitas Ekstrak Biji Pepaya (Carica papaya L) Sebagai Antidiare Pada Mencit Yang Diinduksi Salmonella typhi murium. Jurnal Pangan dan Agroindustri Vol. 3 No. 4 p. 1283-1293.

Garg, et al. (2002). Spreading of Semisolid Formulations. Journal of Pharmaceutical Technology : 84-105.

Herdiana, Yedi. (2007) : Formulasi Gel Undesilenil Fenilalanin Dalam Aktivitas Sebagai Pencerah Kulit. Skripsi. Fakultas Farmasi Universitas Padjajaran, Jatinangor.

Indrawati, Teti. (2010) : Formulasi Sediaan Kosmetik Setengah Padat. Penerbit ISTN : Jakarta.

Irawan, Beni et al. (2013). Uji Aktivitas Ekstrak Etanol 70\% Biji Pepaya (Carica papaya L) Terhadap Kadar Trigliserida Darah dan Kolesterol Total Pada Hati Hampster Yang Diinduksi Aloksan Dan Pakan Tinggi Kolesterol. Fakultas Farmasi dan Sains Uhamka http://ejournal.uhamka.ac.id/files/disk1/5/universitas \%20muhammadiyah\%20prof.dr.ham ka-beniirawan-217-1- jurnalb-2.pdf. Diakses 20 April 2016

Meriyuki, Lieny. (2013). Aktivitas Antibakteri Ekstrak Etanol Biji Buah Pepaya (Carica papaya L) terhadap Escherichia coli dan Staphylococcus aureus. Jurnal Ilmiah Mahasiswa Universitas Surabaya Vol 2 No. 2.

Mitsui, Takeo. (1997) : New Cosmetic Science. Penerbit Elsevier : Amsterdam.

Murtini, Gloria. (2013) : Karbopol Dalam Formulasi Sediaan Gel Dengan Menggunakan Zat Aktif Getah Buah Pepaya (Carica Papaya L). Jurnal $\quad$ Sanitas Vol 6 No. 4 355-362.

Nasution Khairil, et al (2012). Penggunaan Ekstrak Kering Kayu Merbau (Intsia bakeri Prain) Dalam Sediaan Pewarna Rambut. Journal of Pharmaceutics and Pharmacology Vol 1 (2) : 119-124.

Niyogi, et al. (2012). Formulation and Evaluation of Antiinflammatory Activity of Solanum Pubescens Wild Extracts Gel on Albino Wistar Rats. International Journal of Pharmacy. 2 (3) : 484-490.

Nito,2009.Khasiat Buah Pepaya. http:www.conectique.com. diakses 19 Agustus 2012

Paramesti, Niken. (2014) : Efektivitas Ekstrak Biji Pepaya (Carica papaya L) Sebagai Anti Bakteri Terhadap Bakteri Escherichia coli. Skripsi. Fakultas Kedokteran Universitas Islam Negeri Syarif Hidayatullah Jakarta.

ProvitalGroup, (2009). Papaya. Centerchem, Norwalk. http://www.centerchem.com/ Products/DownloadFile.aspx?FileID=6819. Diakses 28 Maret 2016.

Purgiyanti. (2015) : Perbedaan Konsentrasi CMC Na Terhadap Uji Fisik Pewarna Rambut Gel Ekstrak Kulit Buah Durian (Durio zibethinus L). Skripsi. Program Studi D III Farmasi Politeknik Harapan Bersama, Tegal.

Ratih Andi. (2011). Formulasi Gel Ekstrak Etanol Daun Sirih (Piper betle Linn.) dan Uji Aktivitas Antibakteri terhadap Propionibacterium agnes. Skripsi Fakultas Farmasi Universitas Hasanuddin : Makassar. 
Rinayanti, Aprilita. (2009) : Penuntun Praktikum Fitokimia I. Fakultas Farmasi Universitas 17 Agustus 1945 : Jakarta.

Ririn Desty. (2015). Perbandingan Aktivitas Antibakteri Ekstrak Etanol dengan Batang Pepaya (Carica papaya L) terhadap Staphylococcus epidermidis dan Shigella sonnei. Naskah Publikasi Fakultas Farmasi Universitas Muhammadiyah Surakarta : Surakarta.

Rowe R.C, et al. (2009). Handbook of Pharmaceutical Excipients Sixth Edition. Pharmaceutical Press : London, Chicago.

Senthilkumaran Jagadeesh. (2014) : An Overview of Carica Papaya and its Medicinal Uses. Research Journal of Pharmaceutical, Biological and Chemical Sciences Page No. 642

Suara Kaya. (1994) : Biji Pepaya Ampuh Berantas Uban. Kumpulan Kipling Pasca Panen, Peluang Bisnis, Manfaat dan Khasiat Pepaya Hal VII 116.

Sumarny, Ros. (2015) : Uji Penghambatan Proliferasi Dari Beberapa Ekstrak Daun Pepaya (Carica papaya L) Terhadap Sel Tumor MCA-B1 dan MCM-B2 Secara In Vitro. Skripsi. Fakultas Farmasi Universitas Pancasila, Jakarta.

Supomo, et al. (2014). Pemanfaatan Kayu Secang (Caesalpinia sappan L) Dalam Formula Sediaan Pewarna Rambut. Jurnal Kimia Mulawarman Vol II nomor 2, Mei 2014 Kimia FMIPA Unmul : 59-63.

Taufiq Sarah, et al. (2015). Uji Aktivitas Antibakteri Ekstrak Etanol Biji Buah Pepaya (Carica papaya L) terhadap Escherichia coli dan Salmonella typhi. Prosiding Penelitian SpeSIA Unisba.

Tranggono, R.I., dan F.Latifah. (2007). Buku Pegangan Ilmu Pengetahuan $\quad$ Kosmetik. $\quad$ PT Gramedia : Jakarta

Voigt, R. (1994) : Buku Pelajaran Teknologi Formulasi. Penerbit Universitas Gajah Mada : Yogyakarta.

Warisno.2003. Budidaya Pepaya.Kanisius. Yogyakarta.Hal. 15 - 18.

Yuniati, Heru. (1995) : Mengungkap Segudang Khasiat Tanaman Pepaya. Media Litbangkes Vol V No. 02/1995. 